\title{
Total Idiopathic Root Resorption of Permanent Dentition
}

\author{
Reabsorción Idiopática Total de la Dentición Permanente
}

\author{
Claudio Huentequeo-Molina*; Eduardo Borie"* \& Sergio Olate,
}

HUENTEQUEO-MOLINA, C.; BORIE, E. \& OLATE, S. Total idiopathic root resorption of permanent dentition. Int. J. Odontostomat., 7(3):385-388, 2013.

ABSTRACT: Idiopathic external root resorption (IERR) is an infrequent pathology with few accounts in the literature. Treatment has been discussed by various authors but with no consensus. The aim of this article is to describe a new and severe case of IERR in an indigenous 21-year-old woman who came to the Dental Clinic at the Universidad de La Frontera presenting differing degrees of mobility in several teeth, which was increasing progressively with no signs or symptoms of periodontal disease and with no history of former dental treatment, dental trauma or other dentoalveolar pathology; she also did not relate any history of syndromes or systemic diseases. The panoramic x-ray showed varying degrees of external root resorption. To the best of our knowledge, only 3 cases of IERR have ever reported in the literature indicating different treatments; for this patient the treatment indicated was osseointegrated implants in the upper anterior region. Unknown etiology and treatments without consensus make research associated with genetics and molecular biology necessary.

KEY WORDS: root resorption, tooth mobility, permanent dentition.

\section{INTRODUCTION}

Root resorption can be a physiological or pathological process that leads to the loss of cement or dentin, being generally classified as external or internal resorption (Kitahara et al., 2009). This occurs due to an imbalance between the osteoclast and osteoblast activities that maintain the physiological state of the tooth root and the surrounding bone, removing the pre-cement and cementoblasts from the root surface (Sogur et al., 2008). This phenomenon is unpredictable and can be observed in a routine $\mathrm{x}$-ray examination; it is irreversible once it compromises the dentin (Brezniak \& Wasserstein, 1993, 2002; Bilodeau, 2010).

The etiological factors of root resorption are complex, and are associated with a combination of factors, including the individual's biology and genetics, and biomechanical factors (Lee et al., 1999; Hartsfield et al., 2004; Weltman et al., 2010). This pathology is undesirable since it can affect dental stability over the long term and different teeth at different times; although dental treatment has been indicated as a trigger, most cases are of unknown etiology. These cases are called idiopathic external root resorption (IERR) (Snelgrove, 1995).

The term IERR was suggested for the first time in 1985 by Belanger \& Coke (1985), when they found that the origin or the cause of this pathology was not related to systemic or local diseases. The most frequent clinical characteristic of idiopathic root resorption is that patients are asymptomatic with occasional compromise of tooth mobility (Sogur et al.). Currently there is no consensus regarding the treatments recommended for generalized IERR (Sog ur et al.); some authors indicate that the treatment is extraction (Snelgrove), whereas others indicate endodontic treatment (Llena et al., 2002).

The aim of this article is to report and describe an infrequent case of severe IERR in a young indigenous woman affecting the entire permanent dentition.

\footnotetext{
* Programa de Magister en Odontología, Facultad de Odontología, Universidad de La Frontera, Temuco, Chile.

** Unidad de Cirugía Oral y Maxilofacial, Universidad de La Frontera, Temuco, Chile.

*** Centro de Investigación en Ciencias Biomédicas, Universidad Autónoma de Chile, Chile.
} 


\section{CASE REPORT}

Patient, 21 years of age, female, indigenous (Mapuche), came to the Dental Clinic at the Universidad de La Frontera (Temuco, Chile) reporting mobility of the upper anterior teeth. When taking the medical history, the patient reported no trauma, dental treatment or complications during gestation. In addition, the patient had a panoramic $\mathrm{x}$-ray 2 years before (Fig. 1) and reported that neither she nor anyone in her family suffered from any type of systemic disease. A new panoramic $x$-ray was done, observing the existence to external root resorption in every tooth, with reduction in the length of the roots and widening of the periodontal ligament in all the teeth, showing a considerable reduction in the root length of the upper and lower anterior teeth and with minimal bone support in teeth 11 , 12, 21 and 22 (Fig. 2). No increase in the severity of the condition was identified when comparing the two $\mathrm{x}$-rays. For the purposes of determining whether the

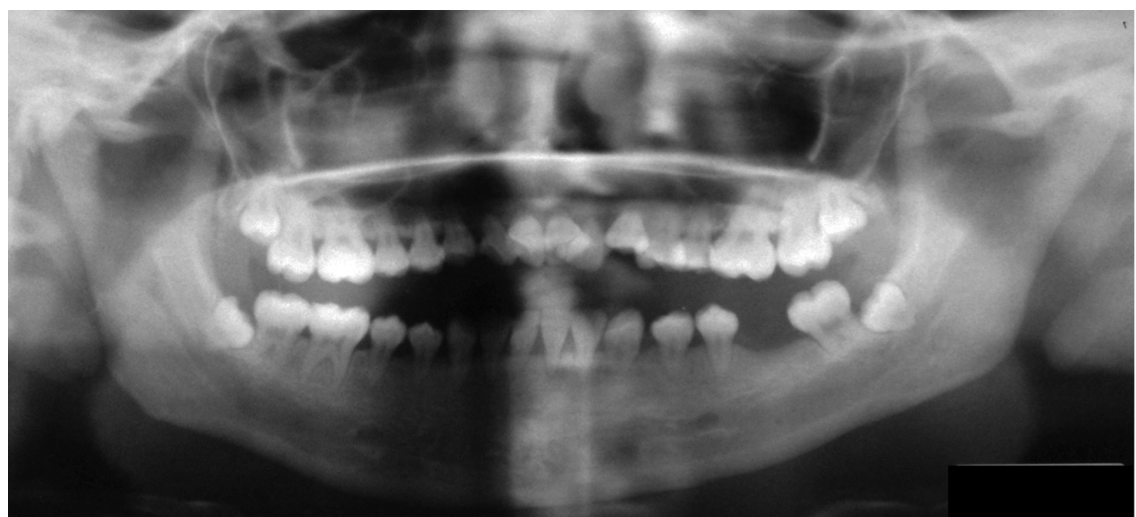

Fig. 1. Panoramic image taken two years prior to initial consultation, showing accentuated root resorptions in several teeth.

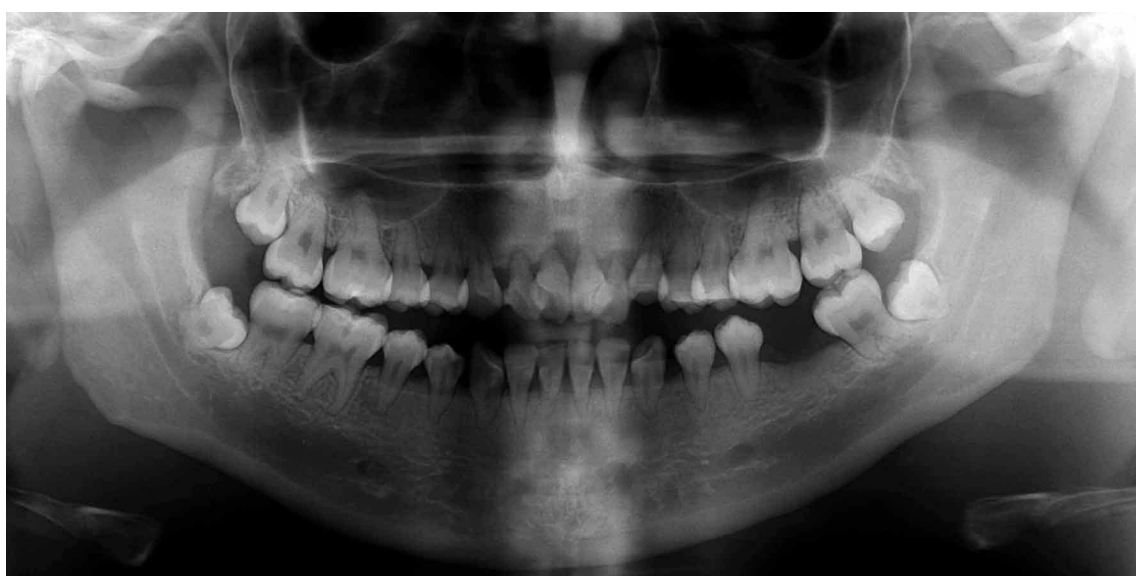

Fig. 2. Present panoramic image, displaying multiple root resorptions in the same teeth; being images from different x-ray equipment, it was not possible to make exact comparisons between the two periods of analysis. same pathology was present in the patient's family, a panoramic x-ray was taken of each of her two siblings, which indicated no signs of root resorption or any other finding in any tooth. The patient's parents were totally edentulous, thereby preventing imaging tests to be performed.

The general examination did not detect any sign or symptom of degenerative, bone, acute or chronic systemic pathologies, presenting non-palpable lymph nodes, both jaws appeared normal and with facial symmetry.

Clinically, the intraoral examination detected an anterior open bite with the absence of 36 , which had been extracted five months earlier due to its advanced mobility. Type I mobility was observed in teeth 13,14 , $15,23,24,25,34,35$ and 45 , type II in teeth $31,32,41$ and 41 and grade III in pieces 11, 12, 21 and 22. Gingivitis was noted in teeth 12, 11, 21, 22, 32, 31, 41 and 42 during the periodontal examination, with no suppurations or increase in local volume or ulcers.

The presence of periodontal disease was not identified how infection process with periodontal pocket; nevertheless, plaque were detected on the lingual surface of the lower anterior teeth and gingiva; all the teeth exhibited pulp vitality with no change in color.

Although the patient did not relate any present or past systemic pathologies, it was decided to study some laboratory tests in order to discard metabolic pathologies; the results were: alkaline phosphatase $161 \mathrm{U} / \mathrm{L}$, calcium $9.8 \mathrm{mg} / \mathrm{dl}$, phosphorus 3.6 $\mathrm{mg} / \mathrm{dl}, \mathrm{T} 3$, triiodothyronine $1.01 \mathrm{ng}$ (ml, T4L, free thyroxine 1,000 ng/ $\mathrm{dL}$ and TSH thyroid-stimulating hormone $3.68 \mathrm{ulU} / \mathrm{mL}$. In addition, other tests such as a hemogram, biochemical profile, lipid profile, liver profile, coagulation tests and glycosylated hemoglobin test presented normal values. 


\section{DISCUSSION}

Root resorption of the permanent dentition is considered a pathological process that can be identified in relation to the dental duct as well as in the area of the cement and dentin (Sog ur et al.).

Severe resorption is defined as exceeding $4 \mathrm{~mm}$ or a third the original length of the tooth, observed between $1 \%$ and $5 \%$ of the teeth (Lupi et al., 1996; Marques et al., 2010, 2011; Weltman et al.), such that our patient presented characteristics that make her stand out as a complex case of root resorption.

Our patient's reason for consultation was similar to that reported by Sog ur et al. (advanced mobility of her upper incisors). The pathology was detected via panoramic X-ray as specified by Rivera \& Walton (1994) and Gupta \& Prakash (2008). In addition, the idiopathic etiology was determined by discarding some possible triggers, such as the absence of orthodontic treatment (mechanical effect), absence of history of systemic disease, absence of root resorption in immediate family (siblings), without symptoms and with normal hematological parameters, among others. The case was diagnosed as IERR in all the permanent teeth in the apical area similar to the cases observed by Belanger \& Coke, Snelgrove and Sog ur et al. It is important to emphasize that Gupta \& Prakash added that clinically IERR involves the normal appearance of the tooth and periodontal tissue, levels of alveolar bone within the normal limits and an absence of local etiological factors. This is consistent with the case at hand.

The treatment for IERR is still not known; however, considering the patient's needs, extraction of the four upper incisors was suggested and rehabilitation with osseintegrated implants, which is in line with the proposals by Bellanger \& Coke and Pankhurst et al. (1998). In addition, the remaining teeth were checked every six months as per the suggestion of Mattison et al. (1983) and Saravia \& Meyer (1989).

Generalized IERR is a very strange phenomenon and very few documented cases have been reported in the literature. In a systematic review from 1965 to 2006 conducted by Sog ur et al., only three cases were reported in which this pathology affected the entire permanent dentition. Additionally, Gupta \& Prakash performed a review from 1930 to 2008 , finding only three cases where the entire permanent dentition was affected, with only one case repeating in both reviews.

In view of the lack of information regarding the etiology and treatment of IERR, research associated with genetics and molecular biology must continue.

HUENTEQUEO-MOLINA, C.; BORIE, E. \& OLATE, S. Reabsorción idiopática total de la dentición permanente. Int. J. Odontostomat., 7(3):385-388, 2013.

RESUMEN: La reabsorción radicular externa Idiopática (IERR) es un fenómeno patológico poco frecuente, con pocos relatos en la literatura. La terapia para esta patología ha sido discutida sin consenso por diferentes autores. El objetivo de este articulo es describir un caso severo de IERR en una mujer indígena de 21 años de edad que concurre a la Clínica Dental de la Universidad de la Frontera debido a la presencia de diferentes grados de movilidad en varios dientes, acentuándose de forma progresiva, sin signos o síntomas de enfermedad periodontal, sin antecedentes de tratamiento de ortodoncia previo, trauma dental u otra patología dentoalveolar, ni antecedentes de síndromes o enfermedades sistémicas. La evaluación radiográfica con imagen panorámica expone diversos grados de reabsorción radicular externa. De nuestro conocimiento solo 3 casos de IERR han sido reportados en la literatura señalando distintos tratamientos; para esta paciente ha sido indicado el tratamiento con implantes oseointegrados en el sector anterosuperior. La etiología desconocida y los tratamientos sin consenso, hacen necesaria la investigación asociada a estudios de genética y biología molecular.

PALABRAS CLAVE: reabsorción radicular, movilidad dentaria, dentición permanente.

\section{REFERENCES}

Belanger, G. K. \& Coke, J. M. Idiopathic external root resorption of the entire permanent dentition: report of a case. ASDC J. Dent. Child., 52(5):359-63, 1985.
Bilodeau, J. E. Retreatment of a patient with Marfan syndrome and severe root resorption. Am. J. Orthod. Dentofacial Orthop., 137(1):123-34, 2010. 
Brezniak, N. \& Wasserstein, W. Root resorption after orthodontic treatment: part 1. Literature review. Am. J. Orthod. Dentofacial Orthop., 103(1): 62-6, 1993.

Brezniak, N. \& Wasserstein, W. Orthodontically induced inflammatory root resorption. Part I: the basic science aspects. Angle Orthod., 72(2):175-9, 2002.

Gupta, R. \& Prakash, V. Bilateral extensive idiopathic apical root resorption in supraerupted maxillary molars: a case report. Oral Surg. Oral Med. Oral Pathol. Oral Radiol. Endod., 106(3):e44-7, 2008.

Hartsfield, J. K. Jr.; Everett, E. T. \& Al-Qawasmi, R. A. Genetic factors in external apical root resorption and orthodontic treatment. Crit. Rev. Oral Biol. Med., 15(2):115-22, 2004.

Kitahara, T.; Takashima, R.; Nakasima, A. \& Kurahara, S. Orthognathic treatment case after severe root resorption in the early treatment stage. Orthod. Waves, 68(1):2835, 2009.

Lee, R. Y.; Artun, J. \& Alonzo, T. A. Are dental anomalies risk factors for apical root resorption in orthodontic patients. Am. J. Orthod. Dentofacial Orthop., 116(2):187-95, 1999.

Llena, M. C.; Amengual, J. \& Forner, L. Reabsorción radicular externa idiopática asociada a hipercalciuria. Med. Oral, 7:192-9, 2002.

Lupi, J. E.; Handelman, C. S. \& Sadowsky, C. Prevalence and severity of apical root resorption and alveolar bone loss in orthodontically treated adults. Am. J. Orthod. Dentofacial Orthop., 109(1):28-37, 1996.

Mattison, G. D.; Gholston, L. R. \& Boyd, P. Orthodontic external root resorption-endodontic considerations. J. Endod., 9(6):253-6, 1983.

Marques, L. S.; Ramos-Jorge, M. L.; Rey, A. C.; Armond, M. C. \& Ruellas, A. C. Severe root resorption in orthodontic patients treated with the edgewise method: prevalence and predictive factors. Am. J. Orthod. Dentofacial Orthop., 137(3):384-8, 2010.

Marques, L. S.; Chaves, K. C.; Rey, A. C.; Pereira, L. J. \& Ruellas A. C. Severe root resorption and orthodontic treatment: clinical implications after 25 years of followup. Am. J. Orthod. Dentofacial Orthop., 139/4 Suppl.):S166-9, 2011.

Pankhurst, C. L.; Eley, B. M. \& Moniz, C. Multiple idiopathic external root resorption. A case report. Oral Surg. Oral Med. Oral Pathol., 65(6):754-6, 1988.

Rivera, E. M. \& Walton, R. E. Extensive idiopathic apical root resorption. A case report. Oral Surg. Oral Med. Oral Pathol., 78(5):673-7, 1994.
Saravia, M. E. \& Meyer, M. L. Multiple idiopathic root resorption in monozygotic twins: a case report. Pediatr. Dent., 11(1):76-8, 1989.

Snelgrove, R. A. Generalized idiopathic apical root resorption as an incidental finding in an adolescent: a case history. Dent. Update, 22(7):276-8, 1995.

Soguur, E.; Sog ur, H. D.; Baski Akdeniz, B. G. \&. Sen, B. H. Idiopathic root resorption of the entire permanent dentition: systematic review and report of a case. Dent. Traumatol., 24(4):490-5, 2008

Weltman, B.; Vig, K. W; Fields, H. W.; Shanker, S. \& Kaizar, E. E. Root resorption associated with orthodontic tooth movement: a systematic review. Am. J. Orthod. Dentofacial Orthop., 137(4):462-76; discussion 12A, 2010.

Correspondence to:

Prof. Dr. Sergio Olate

Facultad de Odontología

Universidad de La Frontera

Temuco

CHILE

Email: sergio.olate@ufrontera.cl

Recibido : 06-06-2013

Aceptado: 03-09-2013 